\title{
PENERAPAN PRINSIP BIOKLIMATIK PADA BANGUNAN RUMAH TINGGAL
}

\author{
Maria Rosita Maharani ${ }^{1}$, Eddy Prianto ${ }^{2}$ \\ Departemen Arsitektur, Fakultas Teknik, Universitas Diponegoro ${ }^{12}$ \\ e-mail: mariarositamaharani@students.undip.ac.id ${ }^{1}$
}

\begin{abstract}
The application of Bioclimatic Principles in buildings is very important, because bioklimatic pay attention to the comfort and welfare of users, as well as providing a positive response to the environment around the building. Therefore, the bioclimatic principles should be applied to closest building scope to every human being. This study takes a case on a residential building located in a densely populated area in the center of Semarang city which is also located in the coastal area. This research was conducted using descriptive analysis method. The purpose of this study is to analize the object of applies the bioclimatic principle, with the hope that it can be used as input for the building of the object in particular and other residential buildings in general to obtain a house that provides comfort and welfare for its users. The results of the study show that the house as the object of this research is able to fulfill 6 bioclimatic principles, which in simple and easy to apply ways. This research show that the bioclimatic principle is very adaptive, it can be applied in the smallest building scope in simple and easy ways for the public.
\end{abstract}

Keyword: Bioklimatic, Comfort, Environment, House

\begin{abstract}
Abstrak
Penerapan Prinsip Bioklimatik pada bangunan sangat penting, karena bioklimatik memperhatikan kenyamanan dan kesejahteraan pengguna, serta memberikan respon positif terhadap lingkungan sekitar bangunan. Oleh karena itu, prinsip-prinsip bioklimatik harus diterapkan pada lingkup bangunan yang paling dekat dengan setiap manusia. Studi ini mengambil kasus pada sebuah bangunan tempat tinggal yang terletak di kawasan padat penduduk di pusat kota Semarang yang juga berada di kawasan pesisir pantai. Penelitian ini dilakukan dengan menggunakan metode deskriptif analisis. Tujuan dari penelitian ini adalah untuk menganalisis objek berdasarkan prinsip bioklimatik, dengan harapan dapat digunakan sebagai bahan masukan bagi bangunan objek pada khususnya dan bangunan tempat tinggal lainnya pada umumnya untuk memperoleh rumah yang memberikan kenyamanan dan kesejahteraan bagi masyarakat. Hasil penelitian menunjukkan bahwa rumah sebagai objek penelitian ini mampu memenuhi 6 prinsip bioklimatik, yaitu dengan cara yang sederhana dan mudah diterapkan. Penelitian ini menunjukkan bahwa prinsip bioklimatik sangat adaptif, dapat diterapkan pada lingkup bangunan terkecil dengan cara yang sederhana dan mudah bagi masyarakat.
\end{abstract}

Kata Kunci: Bioklimatik, Kenyamanan, lingkungan, Rumah

Info Artikel :

Diterima; 2021-10-23

Revisi; 2021-11-09

Disetujui; 2021-11-14

\section{PENDAHULUAN}

Berdasarkan Badan Meteorologi Klimatologi Giofisika (BMKG) kondisi iklim tropis lembab dikota Semarang memiliki suhu relatif tinggi dan kelembaban ratarata $70 \%$, kondisi tersebut menuntut perencanaan tempat tinggal yang dapat merespon iklim dan lingkungan dengan baik untuk mendapatkan hunian yang nyaman, sehat dan ramah bagi lingkungan sekitar. Desain rumah yang menerapkan prinsip ramah lingkungan dan merespon iklim dapat menjadi solusi yang efektif dan tepat sebagai respon terhadap kondisi iklim di kota Semarang. 
Arsitektur Bioklimatik merupakan metode perancangan hemat energi yang memperhatikan iklim setempat dan memecahkan masalah iklim dengan menerapkan pada elemen bangunan (Rosang dalam Cahyaningrum, 2017). Sehingga penerapan arsitektur bioklimatik dapat menjadi solusi yang tepat untuk mendapatkan hunian yang sehat, nyaman dan aman bag lingkungan sekitar.Dalam penelitian ini peneliti akan mengambil studi kasus bangunan rumah tinggal satu lantai yang terletak di pusat kota sekaligus pesisir kota Semarang. Bangunan ini diambil sebagai studi kasus karena lokasinya ditengah kota yang padat penduduk dan terletak didaerah pesisir pantai yang penuh dengan tantangan untuk mendapatkan kualitas hunian yang baik, nyaman dan berkelanjutan

Tujuan dari penelitian ini adalah untuk mendapatan nilai sejauh mana objek studi kasus ini menerapkan prinsip bioklimatik, dengan harapan sebagai bahan masukan bagi bangunan objek studi kasus pada khususnya dan bangunan rumah tinggal lain pada umumnya untuk mendapatkan rumah yang memberikan kenyamanan dan kesejahteraan bagi penggunannya, serta ramah bagi lingkungan sekitar. Penelitian ini dilakukan dengan cara survey langsung ke objek penelitian untuk kemudian dilakukan analisa langsung di lokasi objek penelitian, sehingga mendapatkan data yang lengkap serta akurat.

Desain bioklimatik berdasarkan Hyde (2008) merupakan proses desain menyatukan disiplin fisiologi manusia, klimatologi dan fisika bangunan. Prinsip dari desain bioklimatik yaitu penggunaan desain profesional yang dimulai dari mendesain dengan pertimbangan iklim. Desain bioklimatik fokus pada bentuk penggunaan energi baik energi terbarukan atau tidak terbarukan, efisien energi, kesejahteraan, kenyamanan dan kemudahan bagi pengguna Efisiensi energi harus berporos pada desain dengan sistem mekanikal yang efisien, seperti elemen pasif pada bangunan untuk menyertakan sinergi yang menuntun pada solusi berintregasi. Mengkombinasikan bentuk teknologi baru yaitu dengan tujuan penggunaan nol energi. Konsep karbon netral memiliki tujuan untuk menciptakan daya yang memadai dari energi yang terbarukan yang bersumber dari tempat itu sendiri. Dengan tujuan mendapatkan keseimbangan energi, sehingga tidak bergantung sepenuhnya pada sumber yang tidak terbarukan seperti jaringan listrik dari PLN, diharapkan jaringan Istrik menjadi sebuah sistem cadangan, bahkan dengan harapan pencapaian nol karbon.

Prinsip utama dari desain bioklimatik adalah menciptakan bangunan pasif rendah energi dengan cara menyediakan lingkungan yang nyaman berdasarkan fitur desain pasif. Prinsip kedua adalah mengintegrasikan sistem pasif dan aktif (mekanis, contoh: pendingin ruangan buatan) untuk menciptakan solusi terpadu pengendalian iklim. Penerapan dua prinsip ini bertujuan untuk mencapai kondisi dalam ruangan yang sedekat mungkin dengan kriteria zona nyaman. Oleh karena itu, melalui bentuk dan bahan bangunan, berbagai kondisi luar ruangan dikendalikan untuk mencapai kenyamanan. Namun dalam beberapa kasus, ada batasan untuk penerapan efek sistem pasif. Sehingga solusinya adalah menggunakan sistem aktif untuk saat-saat ketika kenyamanan tidak dapat diberikan oleh sistem pasif. Beberapa strategi integrasi desain pasif dan aktif adalah (1) Interaksi lokasi dan parameter iklim; (2) Sintesis dari lokasi, iklim, dan elemen bangunan; (3) Sinergi antara strategi pengkondisian udara pasif dan aktif (Hyde dan Sunaga, dalam Hyde, 2008).

Beberapa prinsip desain boklimatik yang dapat dipraktikkan menurut Hyde (2008) adalah :

1. Menciptakan kesehatan dan kesejahteraan pengguna

Terdiri dari :

- Bekerja dengan persepsi dan nilai dari pemilik;

- Menciptakan perasaan nyaman;

- Dibangun dengan pemilik yang memperhatikan unsur kesehatan

Program Studi Arsitektur Universitas Pandanaran | kolaborasi jurnal@unpand.ac.id | 29 


\section{Penggunaan Sistem pasif}

Memilih konsep, strategi, elemen dan sistem yang tepat untuk iklim dan tipe bangunan. Menyediakan bangunan yang dapat berevolusi dari bentuk dan tipe untuk menyesuaikan iklim dan konteks sosial

3. Mengelola dan Memulihkan nilai ekologi

Prinsip ini berkaitan dengan tiga hal utama, yaitu "touching the ground lightly", "building foot-printing", dan "consideration of the ecological value of the site". Singkatnya, sebisa mungkin bangunan mengurangi building footprint untuk tetap memberikan ruang hidup bagi anggota lain di dalam tapak. Bangunan hanya bagian dari sistem ekologi tapak, yang tidak boleh menihilkan entitas lainnya.

4. Memanfaatkan energi terbarukan

Energi terbarukan secara alami diregenerasi dalam skala waktu yang singkat dan berasal baik secara langsung maupun tidak langsung dari matahari. Sumber langsung adalah termal, energi fotokimia dan fotolistrik, dan sumber tidak langsung termasuk angin, tenaga air dan energi fotosintesis yang tersimpan dalam biomassa.

Dilakukan dengan 3 pendekatan :
a. Konservasi energi
b. Efisiensi energi
c. Pengurangan bahan bakar fosil

5. Memnfaatkan material terbarukan, Melingkupi strategi:
a. mengurangi intensitas dan dampak sumber daya
b. daur ulang dan penggunaan kembali bahan
c. mengumpulkan sumber daya dari situs

6. Menerapkan pola pikir berkelanjutan

Desain konvensional adalah memikirkan penggunaan pertama bangunan dan tujuan saat itu juga, dengan hanya sedikit memperhatikan penggunaan selanjutnya yang berkelanjutan. Oleh karena itu, berpikir berkelanjutan adalah tentang merancang dari sudut pandang skenario seluruh kehidupan.

\section{METODE PENELITIAN}

Dalam penelitian ini peneliti menggunakan metode penelitian deskriptif analisis, yaitu dengan melakukan analisa objek penelitian berdasarkan teori prinsip bioklimatik, hasil analisa tersebut kemudian dideskripsikan kesesuaiannya terhadap ke-6 prinsip bioklimatik. Data dikumpulkan melalui survey langsung pada objek penelitian, kemudian dilakukan analisa berdasarkan teori prinsip bioklimatik dengan teknik analisa langsung ketika berada dilokasi objek penelitian, sehingga mendapatkan data yang relevan dan akurat.

\section{HASIL DAN PEMBAHASAN}

Pada penelitian ini mengambil objek sebuah bangunan rumah tinggal sederhana yang terletak dikawasan padat penduduk di daerah pusat kota Semarang yang juga berada di kawasan pesisir yang lokasinya hanya sejauh kurang lebih $2,5 \mathrm{~km}$ dari tepi pantai. Pada studi kasus ini akan menilai seberapa besar rumah ini merespon terhadap iklim yang ada dengan dasar prinsip bioklimatik.

- Lokasi objek

Bangunan ini terletak dijalan Erowati 2 no 4 Bululor Semarang Utara, Kota Semarang, sebuah permukiman padat ditengah kota. Rumah ini dibangun dengan memperhatikan iklim setempat yaitu iklim tropis lembab dengan suhu relatif tinggi di Kota Semarang yang sekaligus menjadi permasalahan utama pada rumah tinggal yang terletak didaerah pusat kota yang sekaligus daerah pesisir pantai.

- Deskripsi tapak

30 | Program Studi Arsitektur Universitas Pandanaran | kolaborasi jurnal@unpand.ac.id 
Tapak berada di daerah pesisir pantai yang relatif datar dengan kemiringan 0 $8 \%$, diantara permukimam padat serta sedikit vegetasi, dengan kondisi seperti ini pergerakan angin dikawasan rumah relatif rendah sehingga menyebabkan efek panas dan gerah disekitar lokasi tapak, seperti tampak pada gambar 1.

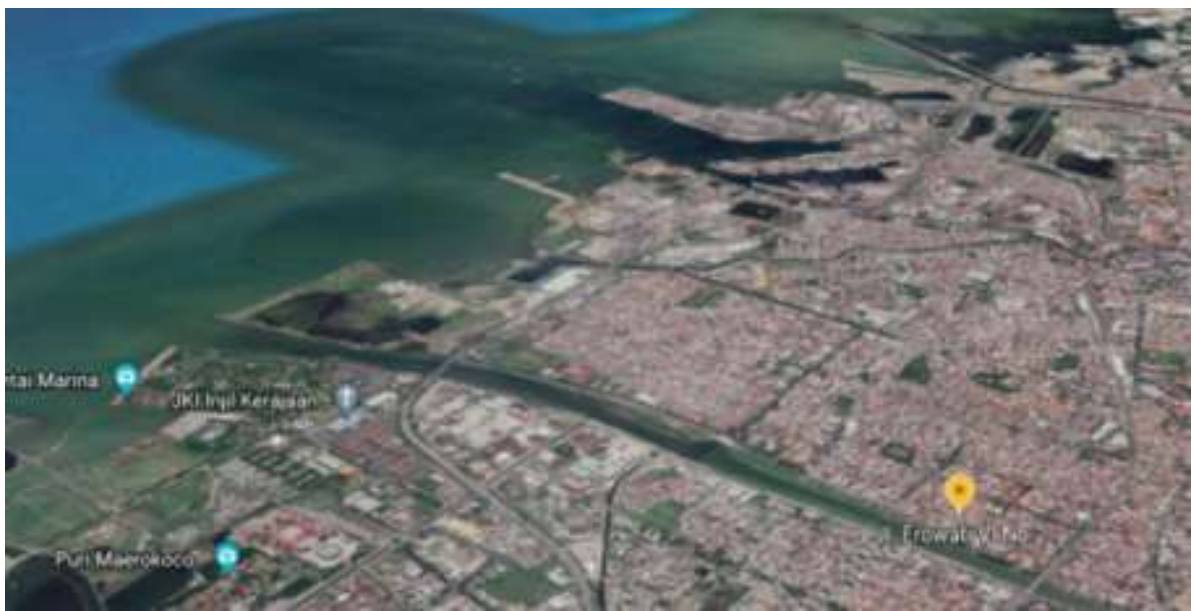

Gambar 1. lokasi tapak (tanda kuning).

- Hasil analisa berdasarkan 6 prinsip bioklimatik

Berikut merupakan paparan hasil analisa objek studi kasus berdasarkan prinsip bioklimatik:

1. Menciptakan kesehatan dan kesejahteraan pengguna

Pada prinsip pertama berikut didapat dari analisa konsep bangunan sebagai berikut:

a. Konsep

Rumah ini mengambil konsep merespon alam, konsep ini diambil sebagai respon untuk menyelesaikan masalah rumah yang berada di kawasan pesisir dan tengah kota yaitu suhu tinggi dan kelembaban yang relatif tinggi yaiu dikisaran $70-80 \%$. Konsep ini diwujudkan dengan menerapkan atribut-atribut desain pasif yang adaptif dan memaksimalkan kondisi lingkungan serta alam. Yaitu diaplikasikan mulai dari penataan layout ruang yang memperhatikan sirkulasi angin, bukaan dan penerangan alami hingga desain rumah yang memiliki bukaan yang lebar.
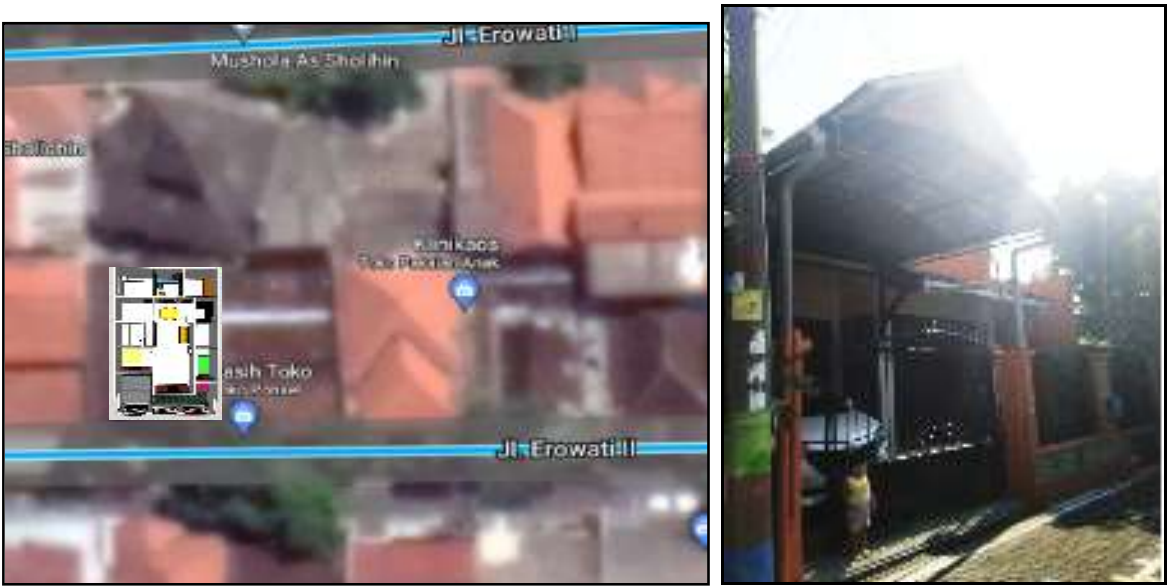

Gambar 2. kondisi lingkungan(kiri) Tampak Depan Bangunan (kanan).

b. Konstruksi dan struktur Bangunan

Rumah tinggal ini dibangun satu lantai dengan sistem struktur rangka beton bertulang. Material utama bangunan terdiri dari besi, beton, batu belah dan

Program Studi Arsitektur Universitas Pandanaran | kolaborasi_jurnal@unpand.ac.id | 31 
kayu yang dibeli dari toko bahan bangunan yang lokasinya tidak jauh dari tapak, sehingga meminimalisir energi yang dikeluarkan. Pemilihan konstruksi atap pelana sebagai respon terhadap iklim tropis untuk menanggulangi hujan dan panas sinar matahari. Atap pelana dipilih dari pada limasan dikarenakan lebih sederhana dalam konstruksi dan material baik jumlah rangka yang dibutuhkan maupun jumlah material genting. Selain itu dengan adanya tritisan dan ruang udara diantara atap dan plafond juga dapat menurunkan perolehan panas dari matahari. Struktur bangunan dapat dilihat pada gambar 3.

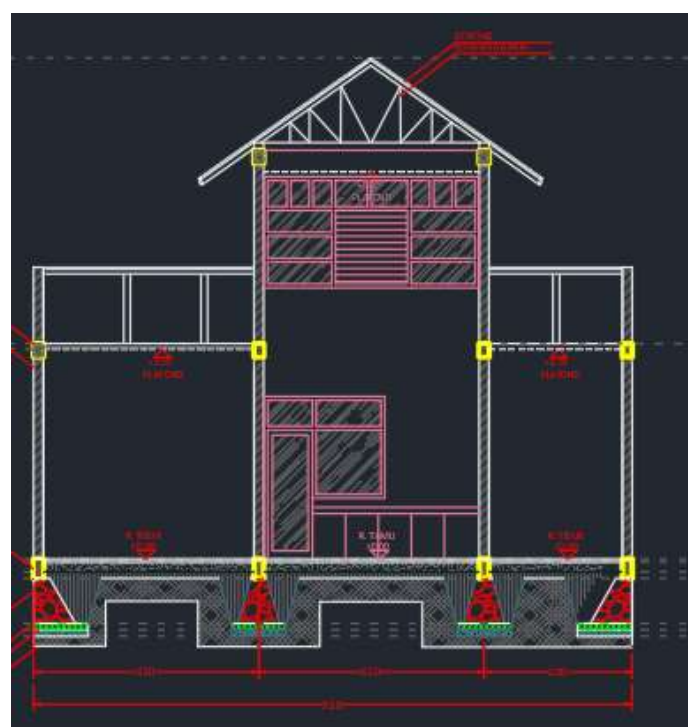

Gambar 3. Potongan Bangunan.

\section{Sistem Pendinginan Pasif}

Bukaan jendela terletak pada arah utara-selatan, tanpa adanya bukaan diarah timur dan barat, sehingga terik sinar matahari tidak masuk langsung kedalam bangunan, malahan mendapatkan manfaat optimal cahaya matahari dari bukaan jendela dan pintu yang terletak di sisi utara dan selatan. Dengan konstruksi atap pelana memungkinkan naungan dan penyediaan ruang atap sebagai penghambat panas masuk kedalam bangunan. Plafond dibuat setinggi $6,5 \mathrm{~m}$ dengan jendela krepyak yang terdapat dibagian atas dan bawah dinding bangunan berfungsi sebagai ventilasi alami yang dapat membantu menurunkan suhu ruang bagian dalam bangunan. Disetiap ruang tidur dirancang memiliki bukaan dan ventilasi alami yang langsung berhubungan dengan udara luar, selain membuat ruang menjadi lebih sehat dan nyaman juga dapat mengurangi penggunaan energi tambahan untuk pendingin ruangan.
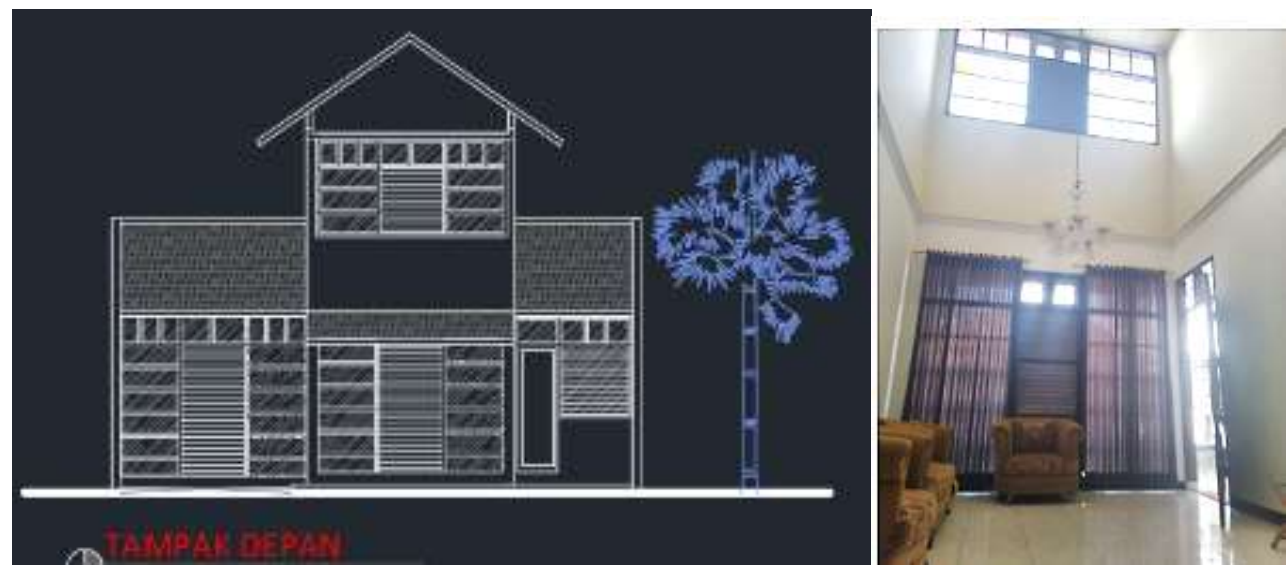

Gambar 4. Strategi sistem pendinginan pasif.

32 | Program Studi Arsitektur Universitas Pandanaran | kolaborasi jurnal@unpand.ac.id 

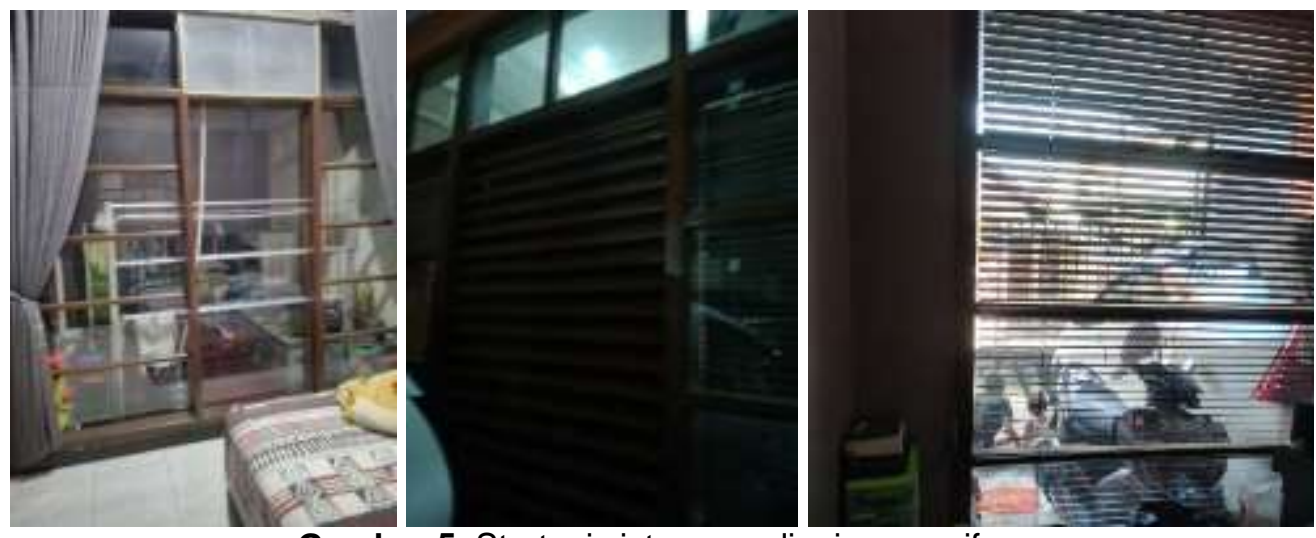

Gambar 5. Strategi sistem pendinginan pasif.

a. Pemaanfatan Cahaya Matahari

Penerangan dalam bangunan pada pagi hingga sore hari memanfaatkan cahaya matahari yang masuk melalui jendela yang terdapat pada bagian utara dan selatan bangunan sehingga tidak memberikan efek silau. Pemanfaatan cahaya matahari pada hari cerah sebagai penerangan alami mencapai $90 \%$ ruang dalam bangunan, sehingga dapat mengurangi pemakaian energi tambahan untuk penerangan buatan dan membuat ruang dalam bangunan menjadi lebih sehat.

b. Naungan Matahari

Penempatan jendela pada bangunan dirancang terletak di bagian utara dan selatan, sehingga dapat memaksimalkan masuknya cahaya matahari tanpa disertai dengan efek silau, ditambah dengan adanya tritisan dengan desain miring diagonal sepanjang $120 \mathrm{~cm}$ disetiap jendela yang selain berfungsi mencegah masuknya air hujan juga berfungsi sebagai naungan matahari.

c. Insulasi

Insulasi dirancang menggunakan insulasi alami yaitu tanaman rambat pada bagian depan dan belakang bangunan. Insulasi ini tidak hanya berfungsi sebagai insulasi thermal namun juga untuk meredam dan mengurangi intensitas suara dari luar bangunan.

\section{Memanfaatkan nilai ekologis}

Ruang terbuka hijau dimanfaatkan untuk penanaman vegetasi dan juga sebagai area resapan air untuk mempertahankan eksistensi jumlah dan kualitas air tanah. Selain itu juga sebagai habitat hidup beberapa hewan seperti burung dan kupukupu dilokasi tapak objek.

\section{Memanfaatkan energi terbarukan.}

Upaya pemanfaatan energi terbarukan dilakukan dengan pendekatan konservasi energi, yaitu dengan pengurangan energi dan juga pendekatan efisiensi energi. Bangunan ini menggunakan berbagai peralatan hemat energi, seperti pemilihan lampu LED. Bangunan memanfaatkan pencahayaan alami di siang hari. Hal ini dapat mengurangi beban energi pada bangunan. Kombinasi dengan peralatan mekanis seperti kipas angin dan pendingin ruangan buatan juga diterapkan untuk menciptakan tingkat kenyamanan yang lebih tinggi diwaktu-waktu tertentu. Perabot elektronik pada rumah ini dipilih yang hemat energi, selain mengurangi beban konsumsi energi lebih pada bangunan, juga mengurangi anggaran biaya yang harus dikeluarkan.

\section{Memanfaatkan bahan berkelanjutan}


Beberapa perabot seperti lemari dan meja kerja memanfaatkan limbah material bekas, penggunaan material cat yang ramah lingkungan untuk menciptakan kualitas bangunan yang lebih sehat juga menjadi salah satu strategi untuk mengurangi dampak negatif bangunan terhadap pencemaran lingkungan. Cahaya matahari yang masuk kedalam ruangan berguna untuk mengusir serangga, selain itu juga membuat kualitas ruang yang lebih baik dan sehat.
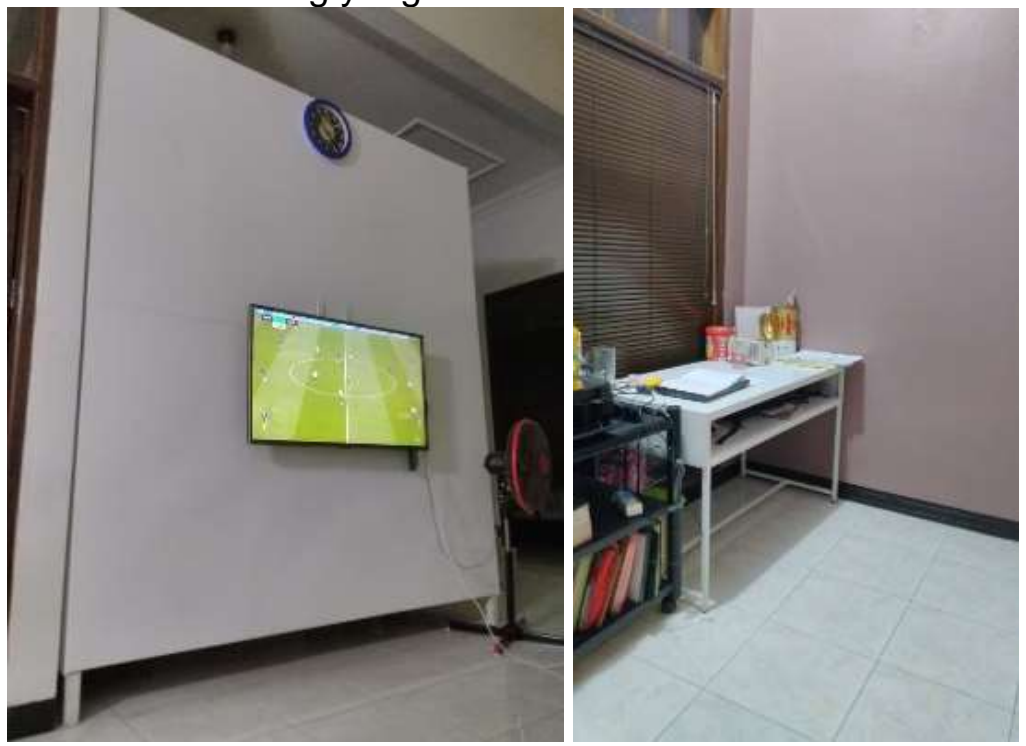

Gambar 6. Pemanfaatan material bekas sebagai perabot.

6. Menerapkan pemikiran life cycle

a. Daur ulang dan konservasi air

Konservasi air dilakukan dengan pembuatan lubang biopori pada area taman, dan juga penampungan air hujan dengan teknik sederhana yang dimanfaatkan untuk menyiram tanaman.

b. Pengolahan limbah

Pengolahan limbah dilakukan dengan teknik sederhana yaitu pemisahan antara sampah organik dan non organik, dimana sampah non organik ini bisa dimanfaatkan ulang untuk berbagai hal. Untuk saat ini sampah non organik dikumpulkan untuk dikomulatifkan pada bank sampah RT.

Tabel 1 Ceklist Penerapan Prinsip Bioklimatik pada Objek Studi Kasus

\begin{tabular}{lll}
\hline No. & \multicolumn{1}{c}{ Prinsip Desain Bioklimatik } & Ket \\
\hline 1. & $\begin{array}{l}\text { Menciptakan kesehatan dan kesejahteraan } \\
\text { pengguna }\end{array}$ & $\mathrm{V}$ \\
\hline 2. & Menggunakan sistem pasif & $\mathrm{V}$ \\
\hline 3. & Mempertahankan nilai ekologis & $\mathrm{V}$ \\
\hline 4. & Memanfaatkan energi terbaharukan & $\mathrm{V}$ \\
\hline 5. & Memanfaatkan bahan berkelanjutan & $\mathrm{V}$ \\
\hline 6. & Menerapkan pemikiran life cycle & $\mathrm{V}$ \\
\hline
\end{tabular}

Keterangan : $\mathrm{v}=$ ada, $\mathrm{x}=$ tidak ada

Enam prinsip bioklimatik yang telah dipaparkan sebelumnya, kemudian diringkas dalam tabel 1. Dari tabel diatas tampak bahwa objek studi kasus menerapkan ke-6 prinsip bioklimatik.

\section{KESIMPULAN DAN SARAN}

Berdasarkan hasil analisa, rumah tinggal yang menjadi objek studi kasus ini telah memenuhi prinsip bioklimatik yang terdiri dari enam poin yaitu, menciptakan kesehatan dan kesejahteraan pengguna, menggunakan sistem pasif, 
mempertahankan nilai ekologis, memanfaatkan energi terbaharukan, memanfaatkan bahan berkelanjutan serta menerapkan pemikiran life cycle. Berdasarkan hasil dari penelitian ini menunjukkan bahwa keenam prinsip bioklimatik mudah daplikasikan oleh kalayak umum mulai dari lingkup bangunan terkecil yaitu rumah tinggal dimulai dengan cara dan teknik yang sederhana, untuk mendapatkan tempat tinggal yang nyaman, menciptakan kesehatan, kesejahteraan pengguna dan memberikan respon yang positif terhadap lingkungan.

\section{UCAPAN TERIMA KASIH}

Terimakasih kepada Narasumber yang telah bersedia memberikan waktu dan kesempatan kepada peneliti untuk melakukan penelitian

\section{DAFTAR PUSTAKA}

\section{Buku}

Hyde, Richard. 2008. Bioclimatic Housing - Innovative Design for Warm Climates. Earthscan: London

\section{Artikel dalam Jurnal}

Barghindi, L, Yashiro,(2019) How can bioclimatic design foster diversification of lowenergy building strategies in the future ?- design for long term learning process in residential building, IOP Conf. Series: Earth and Eviromental Science 294, Tokyo

Cahyaningrum (2017): Implementasi Prinsip Desain Arsitektur Bioklimatik Pada bangunan Perpustakaan Di Klaten, Jurnal Arsitektura Vol.15, 2017

Suryaputri, Endang (2021), Pembayang Pasif Bioklimatik Pada Fasad Terminal Bandar Udara Sukabumi, Trijurnal Trisakti, Jakarta

Wijaya, (2019), Telaah Teori, Metode dan Desain Arsitektur Bioklimatik Karya Ken Yeang, Jurnal Undagi, Bali

\section{Skripsi, Tesis, Disertasi dan Laporan Penelitian}

Fauziyyah, (2020), Penerapan Konsep Bioklimatik pada Perancangan AMICA Apartment Cileunyi, Repository Tugas Akhir Prodi Arsitektur Itenas, Bandung

Mulya, dkk, (2020), Analisa Aplikasi Konsep Arsitektur Bioklimatik Asraa Haji, Rumah Susun dan Sekolah Menengah Kejuruan (Studi kasus : AsramahAJI Embarkasih Medan, Rumah Susun Kayu Putih dan SMK N1 Percut Sei Tuan), Repository Tugas Akhir Prodi Arsitektur Itenas, Bandung

Nudrajat, Fajar, (2020), Penerapan Arsitektur Bioklimatik pada Perancangan City Apartment di Kota Bandung, Repository Tugas Akhir Prodi Arsitektur Itenas, Bandung

Setiadji, D.P, (2020), Penerapan Konsep Bioklimatik pada Perancangan Kalpataru Residences, Repository Tugas Akhir Prodi Arsitektur Itenas, Bandung 